THE GOOD L I F E 

E D W A R D F. F I S C H E R

\section{The Good Life}

Aspiration, Dignity, and the Anthropology of Wellbeing

STANFORD UNIVERSITY PRESS

S T A N F O R D, C A L I F O R N I A 
Stanford University Press

Stanford, California

(C) 2014 by the Board of Trustees of the Leland Stanford Junior University. All rights reserved.

No part of this book may be reproduced or transmitted in any form or by any means, electronic or mechanical, including photocopying and recording, or in any information storage or retrieval system without the prior written permission of Stanford University Press.

Printed in the United States of America on acid-free, archival-quality paper

Library of Congress Cataloging-in-Publication Data

Fischer, Edward F., I966- author.

The good life : aspiration, dignity, and the anthropology of wellbeing / Edward F. Fischer.

pages $\mathrm{cm}$

Includes bibliographical references and index.

ISBN 978-0-8047-9096-3 (cloth : alk. paper) -

ISBN 978-0-8047-9253-O (pbk. : alk. paper)

I. Well-being-Cross-cultural studies. 2. Quality of life-Cross-cultural studies. 3. Economic anthropology-Cross-cultural studies. I. Title.

HN2 5 . $55720 \mathrm{I} 4$

$306-\mathrm{dc} 23$

ISBN 978-0-8047-926I-5 (electronic)

Typeset by Bruce Lundquist in I0/14 Janson 
For Mareike, Fohannes, and Rebecca 
